\title{
Seed Morphology and Post-Seminal Development of Tillandsia L. (Bromeliaceae) from the "Campos Gerais", Paraná, Southern Brazil
}

\author{
Vera Lucia Scatena*, Simone Segecin and Alessandra Ike Coan \\ Departamento de Botânica; Universidade Estadual Paulista; C. P. 199; 13506-900; vscatena@rc.unesp.br; Rio \\ Claro - SP - Brasil
}

\begin{abstract}
This work studied the morphology and post-seminal development of seeds of Tillandsia gardneri Lindl., T. streptocarpa Baker, and T. stricta Sol. ex Sims (Bromeliaceae) from the "Campos Gerais”, State of Paraná, Southern Brazil. The seeds (ca. $2.0 \mathrm{~mm}$ long) presented plumose appendages at their micropylar end, an important structure in the taxonomy of the family since it represented an elaborate apparatus allowing effective winddispersal. Seeds germinated after circa twenty days. The haustorial cotyledon, responsible for the seedling nutrition, appeared first during the germination process. No cataphyll or primary roots developed. A small tank came along in the seedling, formed by the base of the sheath of the first leaf, which overlapped that of the second leaf. This tank can store water and litter. The adventitious roots developed later.
\end{abstract}

Key words: Tillandsia, seed morphology, post-seminal development

\section{INTRODUCTION}

The ecosystem known as "Campos Gerais" in the State of Paraná, Southern Brazil, is a grassywoody steppe-like vegetation interrupted by Araucaria forests, which covers valleys and canyons, or form riparian forests (Veloso et al., 1991). In this vegetation, epiphytic Bromeliaceae species commonly occur, especially Tillandsia, the most representative genus of the family with mostly epiphytic specimens that grow on trunks or rocky slopes. The Bromeliaceae comprises 56 genera and more than 2,600 species, traditionally divided into three subfamilies: Bromelioideae, Pitcairnioideae, and Tillandsioideae (Tomlinson, 1969; Smith and
Downs, 1974, 1977, 1979; Cronquist, 1981; Dahlgren et al., 1985; Leme and Marigo, 1993; Smith and Till, 1998; Judd et al., 1999; Stevens, 2001). The Tillandsioideae consists mostly of epiphytes, with entire leaf margins, distinctive peltate scales, and hair-tufted seeds (Smith and Downs, 1977).

Although several studies have been carried out on the other organs of the plant, mainly their leaves (Braga, 1977; Strehl, 1983; Sajo et al., 1998; Proença and Sajo, 2004; Segecin and Scatena, $2004 a$, b), only a few have been done on seed propagation and seedling morphology of Bromeliaceae species. The work by Gatin (1911) should be highlighted since it described in detail the seed morphology, the germination, and the seedling

* Author for correspondence 
stages of five Bromeliaceae species. In the 80s, Pereira (1988) characterized the main stages of the post-seminal development of 58 Bromeliaceae species, subfamily Bromelioideae, to supply data for seed analysis in laboratorial tests. In the 90s, Tillich (1995) presented some summarized seedling descriptions of several monocotyledons, including Bromeliaceae. More recently, Sajo et al. (2004) compared the micropylar and chalazal appendages of Bromeliaceae seeds and their development in the respective ovules.

According to Tomlinson (1969), the morphology of the seedling stages in Bromeliaceae was important and should be considered in the taxonomic analyses of the group. Also the juvenile stage could be ecologically more significant than the adult one, and might even reveal phylogenetic relationships.

Economically important, most Bromeliaceae are cultivated as ornamentals and sometimes used in traditional medicine. Considering the importance of studies on Bromeliaceae propagation and aiming at future cultivation, this work studied the morphology of the seed and post-seminal development of Tillandsia species from the "Campos Gerais", Paraná, Brazil.

\section{MATERIALS AND METHODS}

The material of Tillandsia was collected in the "Campos Gerais", State of Paraná, Brazil, in environmental protection areas belonging to the Vila Velha and Guartelá State Parks, as well as in the São Jorge Municipal Park. Vouchers of Tillandsia gardneri Lindl. (HUEPG 4465, HRCB 33090), Tillandsia streptocarpa Baker (HUEPG 4420, HRCB 27829), and Tillandsia stricta Sol. ex Sims (HUEPG 4238, HRCB 27835) were deposited in the Herbarium Rioclarense (HRCB) and in the Herbarium of the State University of Ponta Grossa (HUEPG).

Ripe seeds were germinated on moist filter paper in Gerbox, which were sterilized for 15 minutes at $121^{\circ} \mathrm{C}$. They were maintained at $25^{\circ} \mathrm{C}$ and under uninterrupted white light. The substratum was moistened with distilled water at regular periods of three to five days. The seeds were previously treated in a $1 \%$ solution of Carbendazim (Derosal 500 SC). Different stages of germinated seeds and seedlings were fixed in FAA 50 (Johansen, 1940), then transferred and stored in $70 \%$ Ethanol. The description of the seed from germination to seedling stage followed Tillich (1995). The seedling stage was defined from germination to the development of secondary leaves. The different developmental stages, from seed to seedling, were illustrated under a stereomicroscope. The fruits and (soaked and non-soaked) seeds were photographed with micrometric scale projection.

\section{RESULTS}

Since the seed morphology and post-seminal development of the studied Tillandsia gardneri, $T$. streptocarpa, and T. stricta were similar, hence, the results obtained for $T$. stricta, which were more complete, would be presented.

The seeds of the Tillandsia were inserted in dehiscent septicidal capsules (Figs. 1-3). They were spindle-shaped, about $2.0 \mathrm{~mm}$ long (Figs. 4-6), with plumose appendages at their micropylar end (Figs. 4-6 - Ap). The plumose appendages were formed by very numerous single whitish hairs, which grew from the micropyle (Figs. 2-6). The embryo was small, cylindrical, and situated at the base of the starchy endosperm. The germination period occurred circa 20 days after seeds were embedded, with the development of a cotyledon totally modified as a haustorium (Figs. 5-9 - H). During this process, the seeds enlarged and elongated because their constituents increased in size (Figs. 5-8).

No primary root developed. The haustorium $(\mathrm{H})$ was long and tubular (Figs. 6-11). The first leaf $\left(l_{1}\right)$ appeared after 30-40 days; it was entire, green, fleshy, resistant (hard), cupola-shaped, with acuminate apex, slightly curved margins, and dilated-sheathing at the base (Figs. 10-11). In the further development of the 30-40 days seedling, a small tank was formed by the base of the sheath of the first leaf $\left(l_{1}\right)$ that overlaps that of the second leaf $\left(l_{2}\right)$ (Fig. 11). This tank remained in a vertical position because of the presence of the haustorium and of the plumose seed appendages, which helped the seedling to establish on the substrate (Figs. 1011). The second leaf $\left(l_{2}\right)$ developed after 70 days, showing morphological features similar to those of the first leaf (Figs. 10-11). The first adventitious roots, which developed from the base of the stem, 
were only observed during this stage (Fig. 11).

\section{DISCUSSION}

Seed morphology is very diverse within Bromeliaceae species and thus of remarkable systematic significance at the infrafamilial level. The seed coat of the studied Tillandsia presented plumose appendages at their micropylar end. According to Varadarajan and Gilmartin (1988), the Bromelioideae seeds are gelatinous while those of Tillandsioideae possess a plumose flight apparatus. Our results confirmed the occurrence of these structures in the seeds of Tillandsioideae, stressing its importance for the family taxonomy. As for the origin of the plumose appendages of Tillandsia seeds, Sajo et al. (2004) compared them with their respective ovule development. These authors observed that the ovules of Catopsis morreniana and Tillandsia dura presented appendages of both chalazal and micropylar origin, while those of Guzmania madisonii were only of micropylar origin.


Figures 1-6 - Morphological aspects of fruits and seeds of Tillandsia stricta: Fig. 1 - closed capsules. Figs. 2-3 - opened capsules exposing appendaged seeds. Fig. 4 - mature seed. Fig. 5 soaked up seed after 12 days. Fig. 6 - detail of soaked up seed. Ap= plumose appendages; $\mathrm{H}=$ haustorium. Scale bars: Fig. $1=4.0 \mathrm{~mm}$; Fig. $2=2.5 \mathrm{~mm}$; Fig. $3=3.0$ mm; Fig. 4= $2.0 \mathrm{~mm}$; Fig. 5= $1.5 \mathrm{~mm}$; and Fig. $6=0.7 \mathrm{~mm}$. 
Although no study on seed development was carried out in the present work, the presence of plumose appendages at the micropylar end of the seed resembling that of Gusmania madisonii studied by Sajo et al. (2004) was observed. These observations clearly showed that the appendage origin varied much within Tillansioideae, and was an important feature for the group.

According to Smith (1934), the seed appendages of specimens of Tillandsioideae split longitudinally to form numerous filaments constituting a plumage that effectively contributes to anemochory, widely disseminating the seeds that can germinate in most places where they fall. These seed features were also observed in the Tillandsia species studied here and are certainly related to their dispersal success. The cotyledon, not primary roots, was the first structure to develop during the initial stages of germination in the Tillandsia studied here. In these species, the germination process was marked by the appearance of this cotyledon totally modified into a haustorium that was responsible for the seedling nutrition until it achieved photosynthetic capacity and presented absorbing scales in its young leaves. According to Tillich (1995), the haustorial cotyledon acquired the functions of absorption and conduction of food reserves from the endosperm to the seedling.

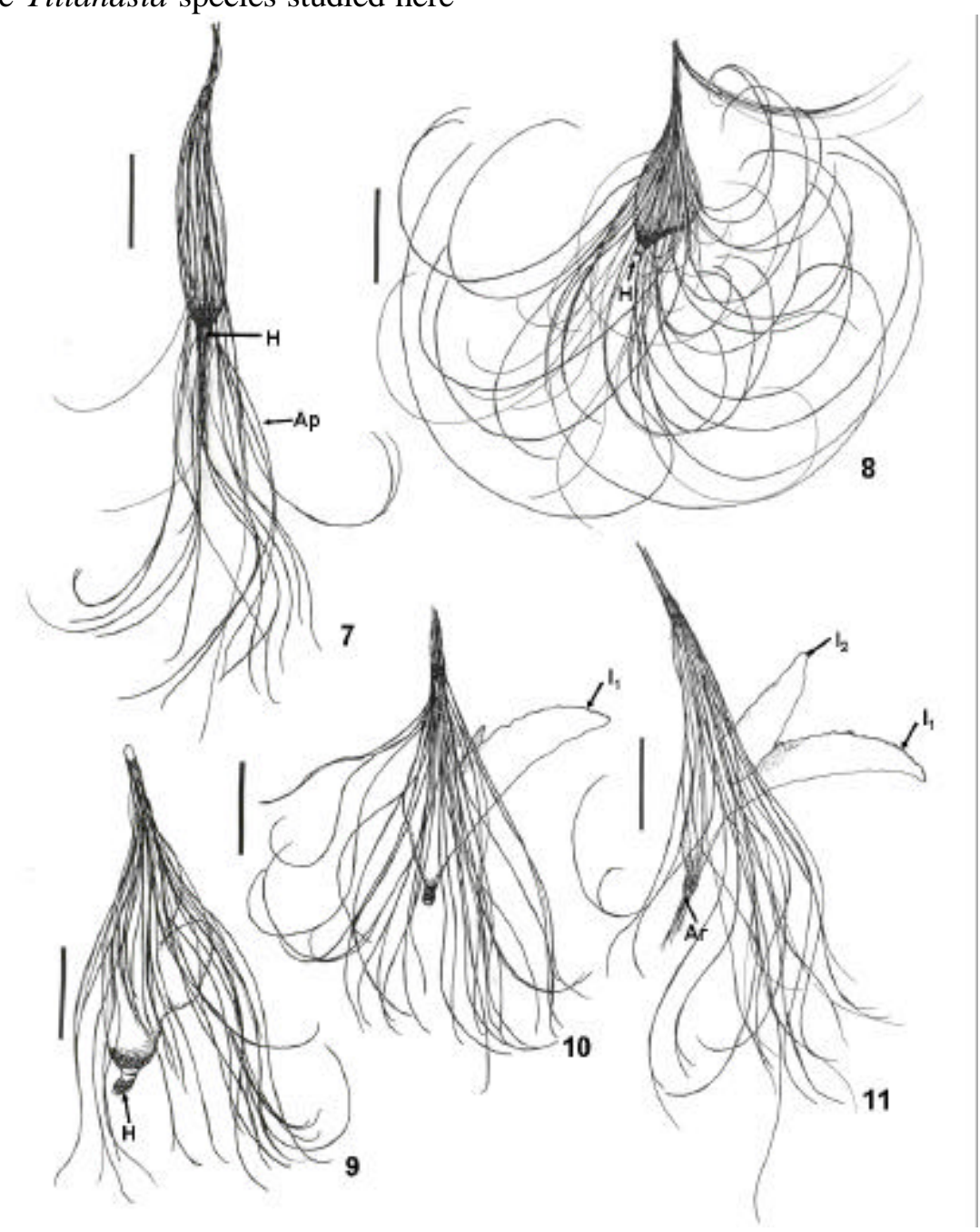

Figures 7-11 - Post-seminal development of Tillandsia stricta: Beginning of the germination period soaked up seed after 4 days (Fig. 7), and after 12 days (Fig. 8). Seedlings with 30 days (Fig. 9), 40 days (Fig. 10), and 70 days (Fig. 11). Ap= plumose appendages; Ar= adventitious roots; $\mathrm{H}=$ haustorium; $\mathrm{l}_{1}=$ first leaf; $\mathrm{l}_{2}=$ second leaf. Scale bars: Figs. $7-$ $11=1.0 \mathrm{~mm}$. 
The morphology of the haustorium of the studied species, quite elongated and tubular, peg-like, may help the seedling stay in a vertical position during its establishment. As for the development of the species studied in the present work, it was noteworthy that although in their adult stage they presented features of extreme atmospheric species, in their juvenile stage (until they develop their second leaf) they showed features of tank-species (young leaves with wide-sheaths constituting a small tank), and negative geotropism.

Lieske (1914) and Schulz (1930) pointed out that during their juvenile phase, the leaves of Bromeliaceae were narrow and ageotropic, which contrasted with the broad leaves and negative geotropism of their adult stage. According to these authors, there was a marked heterophylly between the juvenile and adult phases, usually with a sudden transition from the seedling to the adult stage. They also assumed that the seedling was essentially a "dew-form" (foliar morphology typical of an extreme atmospheric epiphyte; T. usneoides, for instance) with narrow leaves, while the adult was a "rain-form" with broader, gutter-shaped leaves and inflated water-retaining bases. These authors considered that the foliar ontogeny reflected the phylogeny of the group, and that the foliar forms presented in the initial stages of plant development were similar to those of the genus ancestors, with more accentuated xeromorphic features. They regarded the extreme epiphytes as persistent juvenile stages of the tank-epiphytes. Such heterophylly was also observed in the Tillandsia species studied here, but they presented as tank-like specimens in the beginning of their development and as extreme atmospheric (without tank) at the adult stage.

In the studied species of Tillandsia the first leaf of the seedling, which developed soon after the haustorium, presented a wide sheath overlapping that of the second leaf, forming a small tank capable of storing water and probably litter for its own nutrition in native habitats. It was assumed that this tank stayed in vertical position (negative geotropism) for a better use of nutrients by the seedling. Staying in this position was made possible by the presence of the haustorium and of the plumose appendages of the seed coat, which functioned as anchorage structures, helping the seedling to establish on the substrate. The ecological role played by the studied species in their initial stages of development was important and corroborated Tomlinson (1969) who affirmed that the juvenile stages of Bromeliaceae species may contribute to the ecology of the group.

Analyzing the seedling structure of representatives of several monocotyledon families, Tillich (1995) outlined a nomenclature for the group, considering many character states, i.e. cotyledon, seedling axis (hypocotyl), roots and plumular leaves. According to his data, the order Liliiflorae was not well defined by seedling characters and Bromeliiflorae seemed to be a heterogeneous assemblage of orders. Tillich (1995) classified the Tillandsioideae seedlings as lacking primary root, and presenting a compact cotyledon formed by a short sheath and a haustorial cotyledon. The results showed here corroborated this classification and pointed out the absence of both primary roots and cataphylls as a derived state in Bromeliaceae. Following the interpretations by Tillich (2000), absence of primary root and a complete differentiation of a cotyledon into a haustorium should be considered derived character states in seedlings of monocotyledons, shortening the most vulnerable phase of life span.

Analyzing the post-seminal development of some Bromelioideae species, Pereira (1988) noted that germination initiated with the development of a primary root. The author also observed that after the cotyledon base appeared, the main root grew; in most genera this root was about 2.0 to $3.0 \mathrm{~cm}$ long. Only later did the adventitious roots begin to grow, facilitating the plant establishment in the substratum. Pitta (1997) corroborated the data presented by Pereira (1988) in her study on the post-seminal development of Encholirium subsecundum (Bromelioideae), which also reported the development of a primary root during germination.

In the Tillandsia species studied here, which belong to the subfamily Tillandsioideae, no primary root developed during germination, and the appearance of the haustorium was considered as the beginning of the process. As already mentioned above, the Bromelioideae species studied by Pereira (1988) and Pitta (1997) developed primary root. This feature could be important and useful for the 
phylogeny of Bromeliacae, where Tillandsioideae is considered as a derived group.

\section{ACKNOWLEDGEMENTS}

We thank Conselho Nacional de Desenvolvimento Científico e Tecnológico - CNPq, for the research grant to the second author, and Fundação de Amparo à Pesquisa do Estado de São Paulo FAPESP (proc. 05/02141-4) for funding.

\section{RESUMO}

Foi estudada a morfologia da semente e do desenvolvimento pós-seminal de Tillandsia gardneri Lindl., T. streptocarpa Baker, e T. stricta Sol. ex Sims (Bromeliaceae), que ocorrem nos Campos Gerais do Paraná, Brasil. As sementes apresentaram cerca de $2,0 \mathrm{~mm}$ de comprimento e testa com apêndices plumosos na região micropylar. A presença desses apêndices é um caráter importante na taxonomia da família e garante sucesso na dispersão anemocórica das sementes. Após a embebição, as sementes levaram cerca de 20 dias para germinar. A primeira estrutura que emergiu durante a germinação foi o cotilédone haustorial, que é responsável pela nutrição da plântula. Eram ausentes catafilo e raiz primária. Na plântula ocorreu a formação de um pequeno tanque, que é constituído pela base da bainha da folha primária superposta à base da bainha da folha secundária. Esse pequeno tanque permaneceu na posição vertical e armazenou água e detritos orgânicos para a nutrição da plântula. As raízes adventícias emergiram tardiamente.

\section{REFERENCES}

Braga, M. M. N. (1977), Anatomia foliar de Bromeliaceae da campina. Acta Amazonica, 7, 1-74.

Cronquist, A. (1981), An integrated system of classification of flowering plants. New York: Columbia University Press.

Dahlgren, R. M. T.; Clifford, H. T. and Yeo, P. F. (1985), The families of the monocotyledons. Berlin: Springer-Verlag.
Gatin, M. C. L. (1911), Primiéres observations sur le embryon et la germination des broméliacéss. Rev. Gén. Bot., 23, 49-66.

Johansen, D. A. (1940), Plant microtechnique. New York: McGraw-Hill.

Judd W. S.; Campbell, C. S.; Kellog, E. A. and Stevens, P. F. (1999), Plant Systematics: a phylogenetic approach. Massachusetts: Sinauer Associates.

Leme, E. M. C. and Marigo, L. C. (1993), Bromélias na natureza. Rio de Janeiro: Marigo Comunicação Visual.

Lieske, R. (1914), Die heterophyllie epiphytischer, rosettenbildender Bromeliaceen. Jb. Wiss. Bot., 53, 10-502.

Pereira, T. S. (1988), Bromelioideae (Bromeliaceae): morfologia do desenvolvimento pós-seminal de algumas espécies. Arch. Jard. Bot., 29, 115-154.

Pitta, P. B. (1997), Estudo anatômico dos órgãos vegetativos de Dyckia Schultz f. e Encholirium Mart ex Schultz f. (Bromeliaceae) da Serra do Cipó - MG. Dissertação (Mestrado) - Universidade de São Paulo, São Paulo.

Proença, S. L. and Sajo, M. G. (2004), Estrutura foliar de espécies de Aechmea Ruiz and Pav. (Bromeliaceae) do estado de São Paulo, Brasil. Acta Bot. Bras., 18, 319-331.

Sajo, M. G.; Machado, S. R. and Carmello-Guerreiro, S. M. (1998), Aspectos estruturais de folhas de bromélias e suas implicações no agrupamento de espécies. In: Leme, E. M. C. (Ed.). Canistropsis. Bromélias da mata atlântica. Rio de Janeiro: Salamandra. pp. 102-111.

Sajo, M. G.; Prychid C. J. and Rudall, P. J. (2004), Structure and development of the ovule in Bromeliaceae. Kew Bulletin, 59, 261-267.

Schulz, E. (1930), Beiträege zur physiologischen und phylogenetischen anatomie der vegetativen organe der Bromeliaceen. Bot. Arch., 29, 122-209.

Segecin, S. and Scatena, V. L. (2004a), Anatomia de escapos de Tillandsia L. (Bromeliaceae) dos Campos Gerais do Paraná, Brasil. Rev. Bras. Bot., 27, 515525.

Segecin, S. and Scatena, V. L. (2004b), Morfoanatomia de rizoma e raízes de Tillandsia L. (Bromeliaceae) dos Campos Gerais, PR, Brasil. Acta Bot. Bras., 18, 253-260.

Smith, L. B. (1934), Geographical evidence on the lines of evolution in the Bromeliaceae. Bot. Jahrb. fur Systematik, 66, 446-468.

Smith, L. B. and Downs, R. J. (1974), Pitcairnioideae (Bromeliaceae). Flora Neotropica Monographies, 
14, 1-660.

Smith, L. B. and Downs, R. J. (1977), Tillandsioideae (Bromeliaceae). Flora Neotropica Monographies, 4, 663-1492.

Smith, L. B. and Downs, R. J. (1979), Bromelioideae (Bromeliaceae). Flora Neotropica Monographies, 14, 1604-1724.

Smith, L. B. and Till, W. (1998), Bromeliaceae. In: Kubitzki, K. (Ed.). The families and genera of vascular plants. IV. Flowering plants: Monocotyledons - Alismatanae and Commelinanae (except Gramineae). Berlin: Springer-Verlag. pp. 7499.

Stevens, P. F. (2001 onwards), Angiosperm Phylogeny Website. Version 5, May 2004 [and more or less continuously updated since]. Available at: http://www.mobot.org/MOBOT/research/APweb/.

Strehl, T. (1983), Forma, distribuição e flexibilidade dos tricomas foliares usadas na filogenia de bromeliáceas. Iheringia Ser. Bot., 31, 105-119.

Tillich, H. J. (1995), Seedlings and systematics in monocotyledons. In: Rudall, P. J.; Cribb, P. J.; Cutler, D. F. and Humphries, C. J. (Eds.). Monocotyledons: systematics and evolution. Kew: Royal Botanic Garden. pp. 303-352.

Tillich, H. J. (2000), Ancestral and derived character states in seedling of monocotyledons. In: Wilson, K. L. and Morrison, D. A. (Eds.). Monocots: systematics and evolution. Melbourne: CSIRO. pp. 221-229.

Tomlinson, P. B. (1969), Commelinales-Zingiberales. In: Metcalfe, C. R. (Ed.). Anatomy of the Monocotyledons. Oxford: Clarendon Press.

Varadarajan, G. S. and Gilmartin, A. J. (1988), Taxonomic realigments within the subfamily Pitcairnioideae (Bromeliaceae). Syst. Bot., 13, 294299.

Veloso, H. P.; Rangel Filho, A. L. and Lima, J. C. A. (1991), Classificação da vegetação brasileira adaptada a um sistema universal. Rio de Janeiro: IBGE.

Received: June 01, 2005; Revised: September 02, 2005; Accepted: July 21, 2006. 